\title{
WHO IS MY NEIGHBOUR? THE DUTY OF CARE IN THE IMMIGRATION CONTEXT: A PERSPECTIVE FROM CANADIAN CASE LAW
}

\author{
Sasha Baglay*
}

This article reviews and analyzes recent Canadian jurisprudence on immigration-related torts, situating it in the context of the contrasting logic of immigration and tort law. Immigration law's focus on the absolute power of the state to control admission directs courts away from the recognition of the duty of care. In contrast, tort law theory does not preclude the possibility of private law duties to non-citizens, especially in light of the absence of other effective remedies to address the power imbalance between the host state and the non-citizen. The article examines how these two narratives were negotiated in cases of alleged negligence in immigration processing. It problematizes certain aspects of the current construction of the duty of care towards non-citizens and offers some suggestions for a more nuanced understanding of the factors considered under the Anns/Cooper test.

Dans cet article, l'auteure examine et analyse la jurisprudence canadienne récente des délits civils relatifs à l'immigration en la situant dans le contexte de la logique d'opposition du droit de l'immigration et du droit de la responsabilité civile délictuelle. Le droit de l'immigration, qui est centré sur le pouvoir absolu de l'État de contrôler l'admission d'immigrants, fait oublier aux tribunaux la reconnaissance du devoir de diligence. En revanche, la théorie du droit de la responsabilité civile délictuelle n'écarte pas la possibilité d'obligations de droit privé envers des non-nationaux, surtout en l'absence d'autres recours applicables pour résoudre le déséquilibre de pouvoir entre l'État d'accueil et le non-national. Dans cet article, l'auteure étudie la manière dont ces deux discours ont été conciliés dans des cas de négligence présumée dans le traitement de demandes d'immigration. L'auteure définit le problème que posent certains aspects de l'interprétation actuelle du devoir de diligence envers des non-nationaux et présente quelques idées permettant une compréhension nuancée des facteurs pris en compte dans la cause type Anns/Cooper.

\section{INTRODUCTION}

"Who is my neighbour?" This question is at the centre of both immigration and tort law. In immigration law, it allows distinguishing members from the "other" (strangers/non-members), determining the

Associate Professor, Legal Studies Program, University of Ontario Institute of Technology.

Particular reference can be made here to the famous paragraph from Donoghue v Stevenson, [1932] AC 562 (HL) at 580:

"The rule that you are to love your neighbour becomes in law, you must not injure your neighbour ... You must take reasonable care to avoid acts or omissions which you can reasonably foresee would be likely to injure your neighbour. Who, then, in law is my neighbour? The answer seems to be - persons who are so closely and directly affected by my act 
degree of one's inclusion in a host community and his/her corresponding entitlements (or lack thereof). Tort law also distinguishes between neighbours and strangers but does so for the purpose of determining whether a wrong has occurred and whether liability should be imposed. Litigation on the duty of care in immigration-related torts provides an exciting opportunity to explore the constructions of the "other", proximity, and relationships between neighbours and strangers through the contrasting prisms of these two areas of law.

Over the past decade, there have been a number of attempts by non-citizens to sue Canadian immigration authorities for allegedly negligent actions (primarily in relation to application processing). Although courts have largely resisted the recognition of the duty of care, the developed case law raises important questions about the construction of the state - non-citizen relations and the accountability of immigration officials. Yet there has been virtually no scholarly analysis of this jurisprudence and its implications. ${ }^{2}$ There are extensive bodies of literature on immigration and on tort, but they exist in isolation from each other. In the United States, some literature noted the negative impact of immigration law logic on the ability of tort law to perform a compensation function in personal injury cases brought by undocumented migrants. ${ }^{3}$ In Canadian journals, to the author's knowledge, there has only been one article that has attempted to bridge the discussions occurring in the two areas of law. ${ }^{4}$

Given the dearth of scholarship on the subject, the purpose of this article is modest and largely exploratory: to examine the existing case law, to problematize certain aspects of the construction of duty of care towards non-citizens, ${ }^{5}$ and to offer some suggestions for future, more nuanced analysis of these issues. The article is written in three parts. The second part provides a general overview of the case law on immigration-related torts and situates it in the context of underlying logics of immigration and tort law. The third part discusses the application of the test arising from Anns v Merton London Borough

that I ought reasonably to have them in contemplation as being so affected when I am directing my mind to the acts or omissions ... in question."

2 In Canadian journals, there has been only one article - Reem Bahdi, "Reimagining Haj Khalil v Canada" (2009) 27 Windsor YB Access Just 53 - that has engaged with issues somewhat similar to the current article. In addition, an article by Erika Chamberlain, “Abdelrazik: Tort Liability for Exercise of Prerogative Powers?” (2010) 18:3 Constitutional Forum 119, discusses the intentional tort of malfeasance of a public office in immigration context, but it focuses primarily on one specific case and on more technical issues of the Crown prerogative and separation of powers. In the United States, there is some literature on the subject, but it is for the most part focused on a very different and specific issue - the judicial approach to assessment and the award of compensation for personal injuries suffered by undocumented migrants. See, eg, Wendy Andre, "Undocumented Immigrants and Their Personal Injury Actions: Keeping Immigration Policy Out of Lost Wage Awards and Enforcing the Compensatory and Deterrent Functions of Tort Law" (2008) 13 Roger Williams U L Rev 530.

3 Other issues have been raised as well (e.g., the availability of tort law remedy for undocumented migrants who faced assault, false imprisonment, and negligence at the hands of US vigilante groups). See Brooke H Russ, "Secrets on the Texas-Mexico Border: Leiva et al v Ranch Rescue and Rodriguez et al and the Right of Undocumented Aliens to Bring Suit” (2004) 35 U Miami Inter-Am L Rev 405. However, most literature is dedicated to personal injury cases.

4 Bahdi, supra note 2.

5 The article does not seek to offer specific recommendations or to compare the effectiveness of administrate law remedies or Canadian Charter of Rights and Freedoms, Constitution Act, 1982, Schedule B to the Canada Act (1982) (U.K.) [Charter] claims versus those of tort as this issue was addressed elsewhere. See Sasha Baglay, "The Relationship between the Host State and Non-Citizens through the Lens of the Duty of Care" (2013) 21:1 Tort L Rev 3. For a useful discussion of the interrelationship between administrative and tort law principles, see Susan Kneebone, Tort Liability of Public Authorities (Sydney: LBC Information Services, 1998). 
Council, as restated in Cooper v Hobart (the Anns/Cooper test) in current case law on immigrationrelated torts. ${ }^{6}$ The fourth part problematizes certain aspects in current narration of the duty of care and urges for a more in-depth examination of various factors considered under the Anns/Cooper test, which may help produce different outcomes in future litigation.

\section{CASE LAW OVERVIEW AND CONTEXT}

Canadian case law on immigration-related torts is relatively recent and is not particularly extensive. Several cases under analysis are on motions to strike out a claim or for a summary judgment, which indicates that the immigration context is generally not even viewed as an area easily lending itself to the idea of the duty of care.

The examined decisions were located through a Quicklaw search with intentionally broad parameters ${ }^{7}$ and no date restrictions in order to capture all of the cases that discussed the duty of care and to identify the range of contexts in which it was invoked (for example, was it mostly in relation to application processing or enforcement?). Twelve decisions were found: eight dealt with claims arising out of prolonged delays in processing permanent resident applications by refugees ${ }^{8}$ and immigrants; ${ }^{9}$ one concerned a rejection of an immigration application; ${ }^{10}$ one involved immigrants' allegations of negligent misrepresentation of employment opportunities in Canada; ${ }^{11}$ and two were claims by Canadians regarding Canada's failure to take enforcement action against non-citizens ${ }^{12}$ or to properly screen them prior to admission. ${ }^{13}$ In addition, there were three more cases where negligence on the part of Citizenship and Immigration Canada [CIC], the Canadian Security Intelligence Service, the Canada Border Services Agency, and/or consular officials was alleged. ${ }^{14}$ However, in these cases, the duty of

6 Anns v Merton London Borough Council, [1978] AC 728, as restated in Cooper v Hobart, [2001] 3 SCR 537 [Cooper].

7 Quicklaw was searched using the following keywords "duty of care" / $\mathrm{p}$ immigration," "duty of care'/p refugee,"

"negligence /p immigra! or refugee," "duty of care" and investigation and immigra!," "negligence/p CSIS." No date restrictions were applied.

8 Benaissa v Canada (Attorney General), [2005] FCJ No 1487 [Benaissa]; Haj Khalil v Canada, [2008] 4 FCR 53, aff'd Khalil v Canada, [2009] FCJ No 284 (FCA) [Haj Khalil]; Paszkowski v Canada (Attorney General), [2006] FCJ No 248 [Paszkowski].

9 Samimifar v Canada (Minister of Citizenship and Immigration), [2006] FCJ No 1626, aff'd FCA [2007] FCJ No 926 [Samimifar]; Szebenyi v Canada, [2007] 1 FCR 527 [Szebenyi]; Bassij v Canada (Minister of Citizenship and Immigration), [2008] FCJ No 1378 [Bassij]; Farzam v Canada (Minister of Citizenship and Immigration), [2005] FCJ No 2035 [Farzam].

$10 \quad$ Nkunzimana $v$ Canada, [2014] FCJ No 754 [Nkunzimana].

11 In Premakumaran v Canada, [2005] FCJ No 1388 (FC), aff'd [2006] FCJ No 893 (CA) [Premakumaran], the Federal Court allowed a motion for summary judgment against the plaintiffs' action for fraudulent misrepresentation. The plaintiffs claimed that the points system for selection of skilled workers was misleading and that the Canadian government negligently misrepresented that certain job categories were in high demand in Canada. The court found no duty of care.

12 Martin v Canada (Minister of Employment and Immigration), [1999] FCJ No 459 [Martin].

13 Whiteman v Iamkong, [2010] OJ No 966 [Whiteman].

14 In Mohiuddin v Canada, [2006] FCJ No 874, the issue of the duty of care and the defendant's negligence were raised, but they were not addressed by the court in any significant detail. In Almrei v Canada (Attorney General), [2011] OJ No 1764, the plaintiff sought partial summary judgment on liability of the federal government regarding the allegations of negligence, negligent investigation, misfeasance of public office, false imprisonment, and breaches of sections 7, 9, and 
care was merely mentioned and not analyzed in any detail. Therefore, they will not be discussed in the present article.

The article will focus only on the ten cases involving claims by non-citizens in relation to application processing and negligent misrepresentation. The two cases brought by Canadian citizens regarding the lack of proper screening of and/or enforcement against non-citizens will not be discussed as they do not provide sufficient basis to draw any reliable conclusions regarding the construction of the duty of care in relation to citizens: the facts of the cases differ significantly; in one the duty of care was rejected ${ }^{15}$ and in the other it was found "at least arguable" that the duty exists. ${ }^{16}$ Moreover, the nature of the relationship between non-citizens and the host state is distinct from that between the state and its own citizens, and, hence, would not contribute to better understanding of the issues related to claims by noncitizens. $^{17}$

Most of the ten cases that will be examined have similar fact patterns: a non-citizen made an application for permanent residence in Canada, yet several years (and, in some cases, over a decade) later, there was still no decision on the application. In five cases, the delay was partially related to

12 of the Charter, supra note 5. The focus of the judgment was on the issue of estoppel, and it did not address any arguments related to the duty of care. In Abdelrazik v Canada (Attorney General), [2010] FCJ No 1028, the Federal Court ruled on a motion to strike portions of the claim. For more information, see Nathanson Centre on Transnational Human Rights, Crime and Security, online: <http://nathanson.osgoode.yorku.ca/data-bases/abdelrazik-v-minister-offoreign-affairs-et-al/\#compensation>.

15 Martin, supra note 12, involved a claim for damages by a plaintiff who had been sexually assaulted by an individual (identified as P), subject to a removal order. The plaintiff alleged negligence of the immigration department in failing to execute the removal order in a timely manner and, once becoming aware of P's propensity for violence, to protect the interest of Canadians and the plaintiff in particular. The claim failed on the first branch of the Anns/Cooper test as the court concluded that the identified class of "neighbours" was very broad - young, single women living in London, Ontario, and frequenting bars - and thereby not sufficient to create a relationship of proximity. However, the court also indicated that if it were wrong regarding proximity, it could find no considerations that would negate the duty of care.

16 Whiteman, supra note 13 at para 79. In this case, the Ontario Superior Court dealt with a pre-trial motion to strike a claim for damages by a Canadian sponsor who alleged that he had contracted HIV from his spouse, an immigrant to Canada who had worked in the sex trade, due to the negligence of CIC to properly screen her. In allowing the claim against Canada to proceed, the court found that the relationship between the plaintiff and the CIC minister was close enough to create a duty of care and that it was "at least arguable" that negligent investigation may have caused foreseeable harm to the plaintiff. The court assigned importance to the fact that Whiteman, as his spouse's sponsor, had to sign a sponsorship undertaking, which created a contractual or a quasi-contractual relationship between the plaintiff and the CIC minister and, in turn, was a relevant factor in establishing proximity and the duty of care. The court relied on Hill $v$ Hamilton-Wentworth Regional Police Services Board, [2007] 3 SCR 129 [Hill]; Odhavji Estate v Woodhouse, [2003] SCJ No 74 [Odhavji]; and Finney v Barreau du Québec, [2004] 2 SCR 17 [Finney], to support the finding of proximity. In particular, the court noted that similarly to Hill, which dealt with an interaction between the police and an individualized suspect, the case at hand concerned not a universe of all potential immigrants but, rather, a particular immigrant who was medically tested and subject to an undertaking between the minister and the sponsor. It also drew support from Hill on the second stage of the Anns/Cooper test. Whiteman was distinguished from Haj Khalil on a number of grounds, including the absence of other remedies for the plaintiff, the seriousness of the harm alleged, and the consistency between the general duties to the public and the duty of care owed to the plaintiff. Importantly, the court was not satisfied with the defendant's mere assertions that immigration officials owe the duty to the public as a whole and that the law clearly rejects the private duty of care in immigration context.

17 Claims by citizens could be used to contrast the differences between the framing of the duty of care, depending on the plaintiff's immigration/citizenship status, but this issue was touched upon elsewhere. See Baglay, supra note 5. 
inadmissibility. ${ }^{18}$ For example, in Benaissa, the plaintiff was recognized as a refugee under the Immigration Act in 1997 but obtained permanent residence only seven years later (due to concerns over security and criminality). In Samimifar, the applicant's permanent residence application was virtually ignored by the processing officer for seven to nine years. In Haj Khalil, it took CIC more than fourteen years to make a decision on the plaintiff's case. In Farzam and in Szebenyi, Canadians were seeking to sponsor a relative to Canada, and the processing of the relative's application was significantly delayed due to oversights by CIC and/or miscommunication between the parties. ${ }^{19}$

Processing delays are not a mere inconvenience for non-citizens but are a significant obstacle in their daily lives and to their long-term integration and well-being. An individual without permanent resident status must frequently renew his/her work or study permit in order to continue legally working or studying in Canada, cannot sponsor family members to Canada, ${ }^{20}$ and has limited ability to travel outside of Canada and back. Such barriers can be particularly detrimental for refugees who are caught in an impossible limbo. ${ }^{21}$ On the one hand, without the decision on their permanent resident applications, refugees cannot be certain about their long-term future and cannot start meaningful integration in the host country. On the other hand, they usually have nowhere else to go in search of a more certain solution and have little choice but to remain and wait. ${ }^{22}$ For example, Haj Khalil is a stateless Palestinian who cannot return back to her place of origin. Neither does she have an entitlement to enter and reside in any other state. If she were to seek options outside of Canada, she would have to make a refugee claim in another country and go through its refugee determination process. It is unknown whether her claim would be successful. Further, states may impose limitations on access to their refugee determination systems for those who have already been granted refugee status elsewhere. ${ }^{23}$

Although a typical remedy in case of undue delays is an application for mandamus ${ }^{24}$ (and so was pointed out by the courts (for example, in $\mathrm{Haj}_{\mathrm{K}} \mathrm{Kali}^{25}$ )), it cannot adequately address all of the needs of

18 Inadmissibility refers to the circumstances that preclude non-citizens' permanent or temporary admission to Canada. Canadian legislation recognizes the following grounds of inadmissibility: security, violation of human and international rights, criminality, serious criminality, organized criminality, health, financial, misrepresentation, non-compliance with the Act, and inadmissible family member. Immigration and Refugee Protection Act, SC 2001, c 27, ss 34 -42 [IRPA]. Benaissa, supra note 8; Samimifar, supra note 9; Haj Khalil, supra note 8; Farzam, supra note 9; Szebenyi, supra note 9. IRPA, supra note 18.

20 Only a Canadian citizen or a permanent resident can act as a sponsor under the family class. IRPA, supra note 18, s 12(1).

21 For example, while a refugee's application for a work permit is somewhat more streamlined than for other foreign nationals, employers may be reluctant to hire someone who needs to renew work permits on a regular basis. A survey of refugees' experiences in Alberta between 1992 and 1997 found that those without permanent resident status faced major employment barriers, including discrimination on the part of employers. H Krahn et al, "Educated and Underemployed: Refugee Integration into the Canadian Labour Force" (2000) 1:1 J Int'1 Migration \& Integration 59.

22 For a review of the major impacts of limbo on refugees, see Canadian Council for Refugees (CCR), "Refugees in Limbo: A Human Rights Issue" (1999), online: <http://ccrweb.ca/limbo.htm>.

23 E.g., under the Canadian IRPA, a person who already enjoys refugee status in a country other than Canada and can be returned there, is ineligible for a hearing before the Immigration and Refugee Board: IRPA, supra note 18, s 101(1)(d). It may also be possible to advance a Charter claim. E.g., in Blencoe v British Columbia (Human Rights Commission), [2000] 2 SCR 307, the Supreme Court of Canada found that a lengthy delay in proceedings could be sufficiently serious to give rise to a violation of security of the person under section 7 . The Blencoe principles can also be applicable to an immigration context. For an example of a case that pursued both Charter and tort damages (although not in a context of 
the plaintiffs in the examined cases. The limitations stemming from the lack of permanent resident status may result in both economic loss (for example, due to difficulties obtaining and keeping employment) and psychological stress (for example, the feeling of uncertainty and lengthy separation from loved ones), which could rise to the level of harm - an issue that can be properly addressed only through tort law. Further, a successful tort law claim would be more effective in stimulating the authorities to address systemic issues of processing delays and immigration officers' accountability. ${ }^{26}$

\section{A. The Logics of Immigration and Tort Law}

The underlying logics of immigration and tort law make up the framework for judicial analysis of the duty of care in the examined cases and, hence, need to be briefly reviewed.

\section{Immigration Law}

The main premises of immigration law can be summarized as follows. First, immigration law distinguishes between citizens and non-citizens and applies exclusively to the latter. Second, its treatment of non-citizens is governed by the principle that the host state has absolute power to determine the conditions of non-citizens' admission and stay. ${ }^{27}$ Some suggest that immigration law is the "new last

delay), see Vancouver (City) v Ward, [2010] SCJ No 27. Robert E Charney and Josh Hunter, "Tort Lite? - Vancouver (City) v Ward and the Availability of Damages for Charter Infringements" (2011) 54 SC L Rev (2d) 393.

25 E.g., in Haj Khalil, the court noted that mandamus would be an adequate remedy. Haj Khalil, supra note 8 at para 202.

26 For more information, see discussion in section IV of this article.

27 In scholarly literature, there is much debate on whether states have the moral right to exclude "others." E.g., Joseph Carens, "Aliens and Citizens: The Case for Open Borders" (1987) 49 Review of Politics 25; Peter and Renata Singer, "The Ethics of Refugee Policy" in Mark Gibney, ed., Open Borders? Closed Societies? The Ethics and Political Issues (Westport, CT: Greenwood Press, 1988) at 121-122; Michael Dummet, On Immigration and Refugees (London: Routledge, 2001); Michael Walzer, Spheres of Justice: A Defence of Pluralism and Equality (Oxford: Martin Robertson, 1983). See also the academic discussion on the moral underpinnings of refugee protection. E.g., Walzer recognizes a limited duty of states to admit refugees: once the numbers of refugees go up, states will be forced to choose among them, likely selecting those with closer connection to the host community's way of life (at 48-49). See also Mark Gibney, Ethics and Politics of Asylum: Liberal Democracy and the Response to Refugees (Cambridge: Cambridge University Press, 2004), where he argues that states have an obligation to assist refugees as long as the costs of doing so are low.

In contrast, case law and government rhetoric supports the notion of a state's absolute control over admissions. See, e.g., Canada (Minister of Employment and Immigration) v Chiarelli, [1992] 1 SCR 711; IRPA, supra note 18, s 3 (stating objectives of immigration and refugee policy such as "to protect the health and safety of Canadians and to maintain the security of Canadian society"); Honourable Jason Kenney, PC, MP, Minister of Citizenship, Immigration and Multiculturalism, "The Future of Immigration in Canada," Speaking Notes (9 June 2010), online: <http://www.cic.gc.ca/english/department/media/speeches/2010/2010-06-09.asp>; Honourable Jason Kenney, PC, MP, Minister of Citizenship, Immigration and Multiculturalism, “A Balanced Refugee Reform," Speaking Notes (30 March 2010), online: <http://www.cic.gc.ca/english/department/media/speeches/2010/2010-03-30.asp>; Honourable Jason Kenney, PC, MP, Minister of Citizenship, Immigration and Multiculturalism, "Protecting Canada's Immigration System Act," Speaking Notes at a news conference following the tabling of Bill C-31 (16 February 2012), online:

$<$ http://www.cic.gc.ca/english/department/media/speeches/2012/2012-02-16.asp $>$. It is worth noting, however, that cases such as Suresh v Canada (Minister of Citizenship and Immigration), [2002] 1 SCR 3, can be seen as imposing a certain constraint on state immigration power and indirectly imposing a limited duty to protect non-citizens. The Supreme Court of Canada recognized that removal to torture normally would violate the Charter. However, it also noted that such removal may be justified in extraordinary circumstances. 
bastion of state sovereignty. ${ }^{28}$ By tightening immigration regulation, states are attempting to compensate for the loss of sovereignty in other areas. ${ }^{29}$ Immigration law determines both non-citizens' physical access to a given state's territory (for example, through border controls) and their access to membership in the host community (for instance, through criteria for obtaining permanent residence). By controlling access to the two pillars of a nation - territory and community - immigration law is also deemed to contribute to the constancy of a nation and the preservation of its identity. ${ }^{30}$ Third, immigration law is built around the ideas of hierarchy, boundary, and centrality of the host community's interests. The idea of hierarchy is reflected in the differentiation between citizens, permanent residents, and foreign nationals - each status representing a scope of rights on a descending scale from the most extensive for citizens to more limited for permanent residents and foreign nationals. The notion of hierarchy is also reflected in the idea that the rights and interests of the host state/community will usually trump claims of non-citizens. ${ }^{31}$ These hierarchies create not only an outside boundary of a community but also boundaries within, thereby distinguishing members from non-members. The noncitizen status (and, particularly, the absence of legal status in a host country) can in itself be a source of vulnerability that opens the door to differential treatment, marginalization, and even abuse. ${ }^{32}$

Immigrants are usually admitted to a host country under one of three classes: economic, family, or refugee. Economic immigrants are selected on the basis of the skills and/or capital that they can contribute to the host nation; the family class recognizes the value of family unity and is conditional on a sponsor's (rather than the state's) support of his/her relatives; and the refugee class reflects the human rights obligations and humanitarian ideals of the host nation. The immigration class, under which an individual is applying and is admitted to Canada, may be an important factor in elucidating the nature of the non-citizen-host state relationship - an issue key to the determination of the duty of care. For example, for economic immigrants, a rejection of a permanent resident application is not likely to have life-threatening consequences, and, arguably, Canada is not even under an obligation to consider all such applications. ${ }^{33}$ In contrast, refugees are a highly vulnerable group, who require support even prior to

28 Catherine Dauvergne, "Sovereignty, Migration and the Rule of Law in Global Times" (2004) 67:4 Modern L Rev 588 at 588.

$29 \quad$ Ibid.

30 See generally Anthony D Smith, Nationalism: Theory, Ideology, History (Cambridge: Polity Press, 2001) at 146, for a discussion of the "sacred pillars" of a nation.

31 Catherine Dauvergne, "The Dilemma of Rights Discourses for Refugees" (2000) 23 UNSWLJ 56.

32 See, e.g., treatment of temporary foreign workers. D Nakache and P Kinoshita, "The Canadian Temporary Foreign Worker Program: Do Short-Term Economic Needs Prevail over Human Rights Concerns?” (2010), online:

$<$ http://irpp.org/indexe.htm>; Fay Faraday, "Canada's Laws Fuel Migrant Worker Exploitation: Report" (2012), online:

$<\mathrm{http}$ //metcalffoundation.com/publications-resources/view/made-in-canada/>; Tanya Basok, "Post-National Citizenship, Social Exclusion and Migrants Rights: Mexican Seasonal Workers in Canada" (2004) 8:1 Citizenship Studies 47.

33 In 2008, the Budget Implementation Act, 2008, SC 2008, c 28 removed an obligation to process all applications received. In 2012, the Jobs, Growth and Long-term Prosperity Act, SC 2012, c 19, section 707 provided for termination of federal skilled worker files if the applicants applied before 27 February 2008 and the selection decisions on their applications have not been made by 29 March 2012. CIC estimated that approximately 280,000 individuals were affected. See CIC, online: $<$ http://www.cic.gc.ca/english/department/media/notices/notice-qa.asp $>$. In 2014, the same was done with respect to the investor and entrepreneur applications where no selection decision was made by 11 February 2014. Reportedly, the decision affected more than 65,000 applicants. Litigation to challenge the decision was attempted, but it resulted in only partial success. Tabingo v Canada, [2014] FCJ No 863; Liang v Canada, [2012] FCJ No 683. 
receiving protected status or officially becoming members of the host community through the permanent resident process. The Convention Relating to the Status of Refugees obligates states to accord refugees the same treatment as they do to nationals in selected areas ${ }^{34}$ as well as to ensure their non-refoulement to countries of persecution. ${ }^{35}$ Further, in Haj Khalil, the Federal Court recognized that there was a statutory duty to decide a convention refugee's application for permanent residence. ${ }^{36}$ Defined by distinct vulnerability and the applicants' compelling interests, the relationship between the host state and refugees may be seen, arguably, as being more proximate than between the same state and applicants under the economic or family class.

All three immigration classes are subject to inadmissibility screening (although there are some exceptions for refugees), which seeks to prevent admission of individuals who may pose a risk or burden on the host nation. Inadmissibility as a key aspect of any immigration regime highlights immigration law's protective function that is an ever-present priority in relation to all non-citizens. Thus, while immigration law does allow for the admission of desirable applicants, it is equally concerned with promoting and protecting the interests of the host community. The latter becomes particularly important in framing the nature of public and private duties in the duty of care discussions. As mentioned above, while the unique circumstances of refugees may favour the recognition of special obligations by the host state towards them, those obligations would be tempered by the protection "calling" of immigration law (in fact, as noted above, the delays in the examined cases were due precisely to inadmissibility concerns).

\section{Tort Law}

Unlike immigration law, which possesses a relatively fixed identity focused primarily on enhancing the benefits of immigration for the host community and protecting it, tort law seems to have multiple "personalities." Scholarship identifies a range of functions that can be performed by tort law: compensation, deterrence, punishment and admonition, distributive and corrective justice, psychological and educational functions and an ombudsman. ${ }^{37}$ Some accept the pluralistic nature of torts and argue that a unified tort theory is impossible due to these multiple functions and objectives. ${ }^{38}$ Others identify a single key function of tort law around which a given tort theory is structured. For example, the economic approach views deterrence of accidents as the main rationale for tort law liability. ${ }^{39}$ According to it, the fear of liability, as well as the internalization of costs, would create incentives for individuals and businesses to make their activities safer. ${ }^{40}$ The corrective justice approach speaks of the "special

34 These rights include: access to elementary education (art 22(1)), artistic rights and industrial property (art 14), and access to courts (art 16). Convention Relating to the Status of Refugees, 1951, 189 UNTS 150.

35 Ibid, art 33. Note, however, that refoulement may be possible where there are reasonable grounds to consider that the refugee is a danger to the security, or a danger to the community, of the host country.

36 Haj Khalil, supra note 8 at para 170 (although as court noted, this does not automatically indicate the existence of the duty of care).

37 Philip Osborne, The Law of Torts, 2nd ed (Toronto: Irwin law, 2003) at 12-18.

38 Christopher J Robinette, "Can There Be a Unified Theory of Torts? A Pluralist Suggestion from History and Doctrine" (2005) 43 Brandeis LJ 369.

39 See, eg, Guido Calabresi, The Costs of Accidents (New Haven, CT: Yale University Press, 1970); Richard Posner, Economic Analysis of Law, 2nd edition (Boston: Little, Brown, 1972).

40 William M Landes and Richard A Posner, "The Positive Economic Theory of Tort Law" (1980) 15 Georgia L Rev 851. 
morality" of the tort, constructing it as a reflection of an obligation of the wrongdoer to rectify the victim's injury. ${ }^{41}$ Finally, the compensation rationale views tort law as a sort of insurance, focusing on the tort's ability to spread risk and provide meaningful, accessible, and expeditious compensation to victims. ${ }^{42}$

The above theories not only emphasize different rationales of tort law but also project different views on the location of tort law within the private/public divide. The corrective justice approach, which focuses on the parties, supports a traditional view of torts as an area of private law. ${ }^{43}$ In contrast, the economic and compensation approaches touch upon broader issues of cost spreading and risk distribution in society, allowing for consideration of public policy objectives and thereby espousing a public law dimension. ${ }^{44}$ While tort law in the nineteenth century was viewed as a strictly private matter between the plaintiff and the defendant, the twentieth century brought about an increasing realization that tort law was connected to policy and society-wide considerations, leading some to characterize tort law as "public law in disguise." 45

During the late twentieth century, tort law scholarship became increasingly aware of structural and individual power, wealth, and status imbalances, which may have affected tort law's ability to provide remedies to plaintiffs. ${ }^{46}$ For example, it exposed that tort law's reliance on a notion of a "typical or standard person, who turns out to be white, male and middle class" ${ }^{\text {"47 }}$ resulted in limited understanding and recognition of certain types of harm (for example, harms that are perceived to be largely feminine such as emotional and psychological interests and damages related to reproductive systems ${ }^{48}$ ) as well as failure to adequately value certain work (for example, homemaker services ${ }^{49}$ ). The traditional tort law approach to damages that assesses loss by reference to what a plaintiff would have earned in the labour

41 See generally Ernest Weinrib, "The Special Morality of Tort Law" (1989) 34 McGill LJ 403.

42 Christopher J Robinette, “Tort Rationales, Pluralism, and Isaiah Berlin” (2007) 14 Geo Mason L Rev 329 at 346-347.

43 Ibid at 346-347.

44 Ibid at 385-386.

45 GE White, Tort Law in America: An Intellectual History (Oxford: Oxford University Press, 2003) at 219, 338.

46 While the deterrence and corrective justice scholarship have largely reached stability in the 1980s and 1990s respectively, critical scholarship on tort law started to emerge in the late 1980s, most prominently represented by feminist writers. Gary T Schwartz, "Feminist Approaches to Tort Law" (2001) 2 Theor Inq L 1 at 2-4. Eg, Cowie suggested that gender issues must be explicitly addressed when courts deal with relationships between men and women. Jan Cowie, "Evaluating an Issue of Consent in Sexual Battery Cases: Difference, Dominance, Dilemma: A Critical Analysis of Norberg $v$ Wynrib" (1994) 58 Sask L Rev 357. Others note that tort law's agenda should be set at reducing the imbalance in holdings of wealth, status, power, and other goods and empowering the disadvantaged. Tsachi KerenPaz, "An Inquiry into the Merits of Redistribution through Tort Law: Rejecting the Claim of Randomness" (2003) 16 Can JL \& Juris 91 at para 2.

47 Martha Chamallas, "Questioning the Use of Race-Specific and Gender-Specific Economic Data in Tort Litigation: A Constitutional Argument" (1994) 63 Fordham L Rev 73 at 73-74. See also Kate Sutherland, "Measuring Pain: Quantifying Damages in Civil Suits for Sexual Assault" in Ken Cooper-Stephenson \& Elaine Gibson, eds, Tort Theory (North York, ON: Captus Press, 1993) 212.

48 Leslie Bender, "An Overview of Feminist Torts Scholarship" (1993) 78 Cornell L Rev 575; Chamallas, supra note 47 at 74. E.g., Lucinda Finley, "The Hidden Victims of Tort Reform: Women, Children, and the Elderly" (2004) 53 Emory LJ 1263; Lucinda Finley, "The Priceless-Worthless Dilemma: In Defense of Individualized Non-Economic Damages" in DM Engel \& M McCann, eds, Fault Lines: Tort Law and Practice (Stanford, CA: Stanford University Press, 2009); Lucinda Finley, "Female Trouble: The Implications of Tort Reform for Women" (1997) 64 Tennessee L Rev 847. 49 Jamie Cassels, "Damages for Lost Earning Capacity: Women and Children Last" (1992) 71 Can B Rev 447 at 448. 
market tends to reproduce race and class distinctions ${ }^{50}$ and works to undercompensate marginalized groups. ${ }^{51}$ For instance, this is the case with First Nations plaintiffs due to the fact that they have lower statistical indicators of workplace participation, life expectancy, and health outcomes. ${ }^{52}$

Similar findings have been made with respect to racial minorities. ${ }^{53}$ In the case of female plaintiffs, the reliance on sex-based income statistics and the use of female-specific contingency deductions ${ }^{54}$ also resulted in undercompensation in damage awards. ${ }^{55}$ Immigration status has also been noted to affect compensation outcomes. ${ }^{56}$ In some personal injury cases, undocumented immigrants were denied the right to collect lost wages due to their illegal presence in the United States; in others, compensation was allowed but only based on the wage rate of their country of origin (although there have also been cases where the award was calculated based on American wage rates). ${ }^{57}$ Overall, in the cases decided in the United States, immigration policy considerations (namely, deterrence of undocumented migration) tended to have a significant impact on compensation decisions and, in some cases, worked to diminish the compensatory and deterrent functions of tort law. ${ }^{58}$

The present article seeks to explore whether in Canadian cases immigration law logic similarly injected tort law with some preconceived notions about non-citizen-host state relations, which, in turn, created barriers to the recognition of the duty of care. The Anns/Cooper test is the locus of negotiation and construction of relevant public and private interests and is discussed in the following sections.

50 Ibid

51 Elizabeth Adjin-Tettey, "Replication and Perpetuating Inequalities in Personal Injury Claims through Female-Specific Contingencies" (2004) 49 McGill LJ 309.

52 Jamie Cassels, "(In)Equality and the Law of Tort: Gender, Race, and the Assessment of Damages” (1995) 17 Advocates Q 158;

53 Chamallas, supra note 47, shows that the use of race-based income statistics resulted in undercompensation for the African-American and Hispanic population.

54 Upon determining a base annual earnings loss, a trial judge refines the amount of award by considering negative and positive contingencies. Positive contingencies refer to factors that may enhance the plaintiff's potential income and may include promotion, labour productivity increases, and continuing employment after normal retirement age. Negative contingencies impede the earning of income and may include job loss, forced retirement, and disability prior to normal retirement age. In the case of female plaintiffs, the possibility of marriage and child rearing are considered negative contingencies since they are presumed to lead to (at least temporary) withdrawal of the plaintiff from the labour force. See, e.g., Rewcastle Estate v Sieben (2001), 296 AR 61, where an award was decreased by $15 \%$ to reflect such a contingency.

55 Cassels, supra note 52 at 448; Bruce Feldthusen, "Discriminatory Damage Qualifications in Civil Actions for Sexual Battery" (1994) 44 UTLJ 133.

56 For a review of some of the feminist writings in the area, see Bender, supra note 48; Regina Austin, "Employer Abuse, Worker Resistance, and the Tort of Intentional Infliction of Emotional Distress" (1988) 41 Stan L Rev 1; Jean C Love, "Discriminatory Speech and the Tort of Intentional Infliction of Emotional Distress" (1990) 47 Wash \& Lee L Rev 123.

57 Andre, supra note 2.

58 Ibid. See also similar issues raised in Hugh Alexander Fuller, "Immigration, Compensation and Preemption: The Proper Measure of Lost Future Earning Capacity Damages after Hoffman Plastic Compounds, Inc. v. NLRB" (2006) 58 Baylor L Rev 985; Kati L Griffith, "A Supreme Stretch: The Supremacy Clause in the Wake of IRCA and Hoffman Plastic Compounds" (2008) 41 Cornell Int'1 LJ 127; Roxana Mondragon, "Injured Undocumented Workers and Their Workplace Rights: Advocating for a Retaliation Per Se Rule” (2011) 44 Colum JL \& Soc Probs 447. 


\section{CASE LAW ON THE DUTY OF CARE IN IMMIGRATION PROCESSING}

\section{A. The Anns/Cooper Test: An Overview}

In order to succeed on a claim of negligence, a plaintiff must demonstrate that the defendant owed her a duty of care; that there was a breach of that duty; and that the breach caused the alleged harm. Where an establishment of a new duty of care is sought (as is the case in immigration-related torts), Canadian courts apply the two-part Anns/Cooper test:

1. whether the circumstances disclose reasonably foreseeable harm and proximity sufficient to establish a prima facie duty of care;

2. if so, whether there exist residual policy considerations, outside the relationship of the parties, which justify denying the imposition of the duty of care. ${ }^{59}$

The test demonstrates the public-private nature of torts: the first stage focuses on private interests and parties, while the second stage focuses on public interests. The notion of proximity in the first part of the Anns/Cooper test describes the type of relationship in which a duty of care may arise. ${ }^{60}$ It is the connecting factor between the defendant's actions and the plaintiff's loss. ${ }^{61}$ Focusing on the relationship between the parties, proximity assists in deciding whether it is fair and just to impose a duty on the defendant. ${ }^{62}$ Among the factors considered in evaluating proximity are expectations, representations, reliance, property or other interests ${ }^{63}$ as well as issues of policy ${ }^{64}$ but "[t]here is no definitive list. ${ }^{, 65}$

It has been recognized that factors establishing proximity are diverse and depend on the circumstances of the case: "One searches in vain for a single unifying characteristic." ${ }^{66}$ As noted by the Supreme Court of Canada, "[p]roximity may be usefully viewed, not so much as a test in itself, but as a broad concept which is capable of subsuming different categories of cases involving different factors." ${ }^{, 67}$ In fact, some have criticized the notion of proximity as "an empty vessel that can be filled with whatever concoction that its user desires. ${ }^{, 68}$ In their opinion, it is not an analytical device but, rather, a matter of values and policy choices: "[I]t is the values given weight in a case that ultimately decide whether there is proximity or neighbourhood." ${ }^{69}$ As the subsequent discussion of immigration-related torts suggests, host state-centred immigration logic has had a major influence on the construction of proximity becoming one of the key barriers to the recognition of the duty of care. Although the law of negligence

\footnotetext{
59 See also subsequent case law elaborating on the test discussed in section II.B in this article.

60 Cooper, supra note 6 at para 31.

61 GHL Fridman, The Law of Torts in Canada, 2nd ed (Toronto: Carswell, 2002) at 325.

62 Osborne, supra note 37 at $69 ;$ Hill, supra note 16 at para 23.

63 Cooper, supra note 6 at para 34.

64 Ibid at para 30.

65 Syl Apps Secure Treatment Centre v BD, [2007] 3 SCR 83 at para 30 [Syl Apps].

66 Cooper, supra note 6 at para 35.

67 Canadian National Railway Co v Norsk Pacific Steamship Co, [1992] 1 SCR 1021 at 1151, cited in Cooper, supra note 6 at para. 35

68 See generally Allan C Hutchison and Robert Maisey, "Blurred Visions: The Politics of Civil Obligation" in CooperStephenson \& Gibson, supra note 47, 276.

69

Ibid.
} 
normally does not recognize positive duties of care, some factors may "bring parties who would otherwise be legal strangers into proximity and impose positive duties on defendants that would not otherwise exist." ${ }^{70}$ For example, a defendant may be under a positive duty to exercise its public function in a way that minimizes associated risks to the public. $^{71}$

The second branch of the Anns/Cooper test deals with factors outside the relationship between the plaintiff and defendant and takes into account the effect of recognizing the duty of care on other legal obligations, on the legal system, and on society in general. ${ }^{72}$ Essentially, courts are called upon to consider the long-term consequences of imposing liability. ${ }^{73}$ While the test places proximity and residual policy considerations at different stages, the courts have noted that such strict separation may not be necessary: "Provided the proper balancing of the factors relevant to a duty of care are considered, it may not matter, so far as a particular case is concerned, at which 'stage' it occurs. The underlying question is whether a duty of care should be imposed, taking into account all relevant factors disclosed by the circumstances." 74

\section{B. Duty of Care and Liability of Public Bodies and Officials}

The application of the Anns/Cooper test has some peculiarities in the context of liability of public officials and bodies - an issue of direct relevance to immigration processing. Although ordinary negligence principles apply to the Crown, the scope of its liability may be more limited compared to other entities. ${ }^{75}$ The approach to the liability of public entities reflects the "justice-governance" tension. On the one hand, aggrieved individuals need to have a remedy (a justice concern), but, on the other hand, administrative authorities should be able to exercise discretion and formulate policy without the threat of legal proceedings (a governance concern). ${ }^{76}$ This is found, for example, in the consideration of the policy/operational nature of government decisions under the second stage of the Anns/Cooper test. An operational decision may attract liability, while a policy decision cannot. ${ }^{77}$

Childs v Desormeaux, [2006] 1 SCR 643 at para 34.

Ibid at paras 37-38.

Edwards v Law Society of Upper Canada, [2001] 3 SCR 562 at para 10 [Edwards].

Fridman, supra note 61 at 328.

Cooper, supra note 6 at para 27.

75 Ontario Law Reform Commission, "Report on the Liability of the Crown" (1989) at 17. The report recommends that all privileges and immunities with respect to Crown liability be abolished. The existence of such privileges and immunities not enjoyed by others contradicts the principles of popular and accountable government and the rule of law.

76 David Stratas, "Damages as a Remedy against Administrative Authorities: An Area Needing Clarification," online: $<$ http://www.davidstratas.com/24.pdf $>$.

77 A policy decision is usually considered to be one involving financial, economic, social, and political considerations, whereby an authority attempts to strike a balance among various considerations. Operational decisions are related to the implementation of policies and are usually made on the basis of technical standards, expert opinion, and administrative direction. See Just v British Columbia (1989), 64 DLR $\left(4^{\text {th }}\right) 689$. Although useful at first blush, the distinction between the two types of decisions is ambiguous and has been much criticized. E.g., Peter Bowal \& Lynn Boland, "Crowning Glory: Liability in Negligence of Public Authorities Revisited" (1994) 24 RDUS 435; Lewis N Klar, "Recent Developments in Canadian Law: Tort Law" (1991) 23:1 Ottawa L Rev 177; Kevin Woodall, "Private Law Liability of Public Authorities for Negligent Inspection and Regulation" (1992) 37 McGill LJ 83. See also A. Linden \& B.

Feldthusen, Canadian Tort Law, 8th ed (Toronto: Butterworths, 2006) at 696-697, for the survey and analysis of various criticisms of policy/operational distinction. 
The framework for determining novel duties of care with respect to public bodies/officials can be found in a series of Supreme Court of Canada decisions from the past decade. ${ }^{78}$ Its key points, most of which relate to proximity, can be summarized as follows. First, the analysis of proximity is to be grounded in a governing statute and the nature of duties it imposes. This approach has created formidable challenges to plaintiffs since statutes "almost inevitably" impose public duties on regulators. ${ }^{79}$ Where the legislative scheme expressly or implicitly forecloses a private law duty of care, the Anns/Cooper inquiry ends at that point. However, if legislation does not clearly indicate one way or the other, courts may proceed to examine the nature of the relationship between the public body and the plaintiff.

Second, a range of factors may impact the findings of proximity: a potential conflict between a public and a private duty; the compelling interests at stake; the absence of alternative remedies; and the existence/absence of direct interaction between the plaintiff and defendant. The impact of these factors may may be as follows. A potential conflict between a public and a private duty may militate against the finding of proximity. However, as noted in Hill, "conflict or potential conflict does not in itself negate a prima facie duty of care; the conflict ... must pose a real potential for negative policy consequences. ${ }^{" 80}$ In contrast, consistency between a public and a private duty may assist in establishing proximity. For example, in Hill, the majority took note of the public interest in police accountability that may be advanced by the tort of negligent investigation and consistency of the duty of care with the values of the Charter ${ }^{81}$ Similarly, in Odhavji, the existence of a statutory duty and a reasonable expectation of the public regarding investigation of police misconduct weighed heavily in favour of recognizing the chief of police's duty of care towards the family of a suspect shot by the police. ${ }^{82}$

The compelling nature of interests at stake for the plaintiff and the absence of alternative remedies may also favour a finding of proximity. For example, in Hill, which dealt with negligent police investigation, the finding of proximity was supported, inter alia, by the interests engaged ("[a]t stake are his freedom, his reputation and how he may spend a good portion of his life" ${ }^{83}$ ) as well as the absence of alternative remedies (" $[\mathrm{t}] \mathrm{o}$ deny a remedy in tort is, quite literally, to deny justice" ${ }^{\prime 4}$ ). The absence of alternative remedies was also noted in Odhavji. ${ }^{85}$

Third, a distinction can be drawn between cases where there is direct interaction between the plaintiff and the defendant (for example, Hill) and those where a public authority regulates a third party, which, in turn, interacts with the plaintiff and causes harm to the plaintiff (for example, Cooper and Edwards. ${ }^{86}$

78 Cooper, supra note 6; Edwards, supra note 72; Odhavji, supra note 16; Finney, supra note 16; Syl Apps, supra note 65; Hill, supra note 16; Fullowka v Pinkerton's of Canada Ltd, [2010] 1 SCR 132 [Fullowka]; R v Imperial Tobacco Canada Ltd, [2011] SCJ No 42.

E.g., in Imperial Tobacco, the Supreme Court of Canada noted that given that statutes are usually pursuing public good, "it may be difficult to find a statute that creates sufficient proximity to give rise to a duty of care." See also Taylor $v$ Canada (Attorney General), [2012] OJ No 3208 at para 78 [Taylor].

${ }^{80}$ Hill, supra note 16 at para 40.

81 Charter, supra note 5.

82 Odhavji, supra note 16 at para 57-58.

83 Hill, supra note 16 at para 34.

84 Odhavji, supra note 16 at para 35.

85 Ibid at para 60.

86 In Cooper, supra note 6, the action was brought by investors who advanced their money to an unscrupulous mortgage broker and suffered losses as a result. It was alleged that the registrar was aware of the broker's violations but failed to 
A finding of proximity may be more readily made in the first scenario. ${ }^{87}$ For example, Cooper and Edwards, in which the duty of care was denied, both dealt with alleged negligence of regulators to properly supervise private entities (a mortgage broker and a lawyer respectively), which caused harm to the plaintiffs. The Court concluded that the regulators owed a duty to the public as a whole and that a private duty would "potentially conflict" with the regulator's public duty. ${ }^{88}$ In contrast, Hill, where a duty of care was found, involved a personal, close, and direct relationship between the police and the identified suspect. In Fullowka, the closeness between the mining safety regulators and the miners fell, on the spectrum, somewhere in between Hill and Cooper and Edwards but, ultimately, was determined to be sufficiently close and direct to give rise to a prima facie duty of care.

The above discussion suggests that the current approach to liability of public bodies does not automatically preclude the recognition of a duty of care in the immigration context. However, one can expect formidable challenges in mounting successful claims since the impact of these discussed factors is likely to be mixed - with some favouring proximity and others not. For example, direct interaction between applicants and immigration authorities (which is always present in one form or another and is different from situations in Cooper and Edwards) would support proximity. So would the applicant's compelling interests (for example, those of refugee applicants). However, as noted before, not every immigration application would have such strongly compelling interests at stake so as to favour proximity. For example, interests of economic immigrants to improve their employment or other opportunities would likely not rise to that level. Other factors - the nature of the legislative scheme and the nature of public/private duties - may favour or militate against proximity, depending on how courts construe them and the extent to which such construction is influenced by the immigration law logic. For example, interpreting the interests of the host community and those of applicants as always opposing and mutually exclusive would likely lead to the finding of a lack of proximity. The opposite, however, may support proximity.

\section{Narrating the Duty of Care in the Immigration Context}

The ten examined cases involved the following types of claims: five cases involved refugees awaiting decisions on permanent residence ${ }^{89}$ (Benaissa (2005), Samimifar (2006), Paszkowski (2006), Haj Khalil (2007), Bassij (2008)); two cases involved delayed family sponsorship applications (Farzam (2005) and Szebenyi (2006)); one case involved the rejection of a sponsorship application (Nkunzimana (2014)); and one case involved a claim of negligent misrepresentation of immigration opportunities in Canada. In all but one case, the courts found no proximity between the plaintiff and the Crown. Despite recognizing that there was no prima facie duty of care, the courts usually proceeded to the second stage of the Anns/Cooper test where they determined that several factors militated against the duty of care, namely the existence of alternative remedies by way of mandamus, ${ }^{90}$ the risk of indeterminate liability, ${ }^{91}$ and the

promptly suspend its licence. In Edwards, supra note 72, the plaintiffs deposited money in a solicitor's trust account and the money was lost as a result of fraudulent activity. It was argued that the Law Society failed to take effective steps to ensure that the trust account was operated properly.

87 Taylor, supra note 79 at para 87.

88 Cooper, supra note 6 at para 44.

89 Even in case of applications by refugees, the cases have crossed into the area of immigration law as they are dealing not with conferral of protection but, rather, with permanent residence.

90 Haj Khalil, supra note 8 at para 202. 
concern that the imposition of a duty of care would hamper the effective performance of immigration control. $^{92}$

Benaissa, the first reported case of this sort, addressed the duty of care in obiter in the context of a decision on a motion to strike out a claim. In denying the duty of care, the court relied on two major considerations. First, the governing statute - the IRPA - did not require CIC to observe any deadline in processing permanent resident applications. ${ }^{93}$ Second, the 1997 decision of the English Court of Appeal in $W$. $v$ Home Office was used as a guide to determine the proper limits on private duties in the immigration context. ${ }^{94}$ In this case, a Liberian asylum seeker was kept in detention due to a mistake by the immigration officials. ${ }^{95}$ The English court reasoned that a duty of care would be inconsistent with the performance of immigration control and that only deliberate abuse of immigration powers could justify a private law remedy. Correspondingly, a Canadian court concluded that it would not be "just, fair and reasonable" to impose a duty of care in the absence of "bad faith, gross negligence, or undue delay"; simple mistakes should not give rise to tort liability. ${ }^{96}$

A subsequent decision in Farzam gives more detailed consideration to the duty of care but similarly relies on Home Office and the IRPA's construction of immigration as a privilege. It concluded that it would not be fair or reasonable to impose a duty of care in the absence of "bad faith, misfeasance, or abuse of process. ${ }^{997}$ The court reasoned that immigration officers owed a duty to the public as a whole and a private duty would interfere with it. Farzam's reasoning was adopted in Szebenyi and Paszkowski. The application of Home Office and the notion of immigration as a privilege led to the establishment of a high threshold for recognition of the duty of care: "bad faith, misfeasance, or abuse of process" (note that Benaissa spoke of "bad faith, gross negligence or undue delay," which may be interpreted as a somewhat lower threshold). The relatively weak facts of Benaissa, Farzam, and Szebenyi allowed CIC oversights to be construed as minor mistakes by officers who otherwise diligently performed their job and, therefore, did not rise to the level of "bad faith, misfeasance, or abuse of process." For example, in Benaissa (which involved a seven-year delay in the decision on the plaintiff's permanent residence due to concerns over security and criminality), the decision did not disclose any details regarding the reasons for the delay but noted that the claimant's assertions about negligence of the Crown were not materially substantiated.

In Farzam, the sponsorship of the plaintiff's wife (Ms Mohiti) was delayed because CIC mistakenly opened two files on her. ${ }^{98}$ By the time a minister's permit was issued to her, she had divorced the

91

95 [1997] EWJ No 3289 [Home Office].

5 The plaintiff could not be released until it was ascertained that he was indeed from Liberia. As a rule, to determine that, individuals were given a test with basic questions about Liberia. Somebody else's test results (with a very low score) were mistakenly placed in the plaintiff's file. Since his origin from Liberia could not be ascertained, he remained in detention for a period of time.

96 Benaissa, supra note 8 at para 39.

97 Farzam, supra note 9 at para 102. Home Office, supra note 94.

98 Mr Farzam who came to Canada as a refugee initiated efforts to bring his wife (Ms Mohiti) to Canada in 1990. She was sent an application kit in April 1990 but submitted it only in October 1992. The minister's permit was issued to her in 1994. 
plaintiff. Mr Farzam attributed the divorce and his resultant depressive state to CIC's negligence in processing his application (the plaintiff contended that Ms Mohiti thought that he was at fault for the delays). However, the record showed various attempts by CIC to assist the plaintiff, including even sending a letter explaining the mistake with a hope that "this helps convince your wife that you are not at fault in the length of time it took to finalize her case." 99

In Szebenyi, a family sponsorship was delayed, in part, due to the misfiling of information by CIC. In 1994, the plaintiff's parents were determined to be inadmissible (due to the mother's diabetes) and were advised of two options: either to apply for a minister's permit or to repeat the medical examination. They chose the latter and conducted two more examinations. The second examination showed a different result, which potentially meant that the mother was not inadmissible. However, the results expired due to delays by the examining physician, and an examination had to be repeated. In 1997, the third examination showed the same result as the second, but it was misfiled by CIC, which then requested additional tests and medical information. The mother did not undergo those tests (on the advice of her son who considered that the tests were not required and were not reasonably requested). As a result, in 2000, the application was refused due to medical inadmissibility. The excerpts from CIC's internal correspondence supported the impression that CIC had made several attempts to assist the plaintiff overcome barriers related to inadmissibility. In light of this evidence, the misfiling of information could have been perceived as a relatively minor omission of an otherwise diligent CIC. The court rejected as unsubstantiated the plaintiff's allegations that CIC unreasonably rejected medical reports or unreasonably asked for further medical tests.

Haj Khalil involved arguably more compelling facts and the lengthiest delay (some fourteen years) in the examined group of cases. The applicant was recognized as a convention refugee in 1994 and made an application for permanent residence in 1995. Some fourteen years later, she was still awaiting a decision. Haj Khalil was a member of Fatah and a journalist for a Fatah-controlled Palestine Liberation Organization [PLO] publication. Canadian immigration authorities concluded that she was inadmissible on security grounds, namely membership in an organization for which there were reasonable grounds to believe it engages, has engaged, or will engage in terrorism. In the officers' opinion, Fatah had engaged in terrorism during Haj Khalil's employment, and Ms Haj Khalil would have been aware of the organization's ideology and terrorist actions. ${ }^{100}$ An inadmissible individual, as a rule, would not be granted permanent residence unless he or she obtains a ministerial exemption (for which Haj Khalil had applied). Given the backlog at the time, CIC decided to prioritize inadmissibility files and "park" ministerial relief cases. As a result, in 2007, when the tort claim was heard, the decision on Haj Khalil's case still remained outstanding.

$99 \quad$ Farzam, supra note 9 at para 67.

100 Note that there have been several determinations on Haj Khalil's inadmissibility. During the first consideration of her file, an officer determined her inadmissible on the basis of membership in the PLO, but this conclusion was overturned on judicial review. A second officer also found Haj Khalil inadmissible on the basis of membership in and employment by the PLO. This decision was overturned on judicial review on consent of the minister. A third officer found Haj Khalil inadmissible due to her membership in Fatah. That conclusion was also overturned on judicial review on consent of the minister. Finally, a fourth officer found Haj Khalil to be inadmissible on the basis of her membership in Fatah. This decision was upheld as reasonable by the Federal Court. See Khalil v Canada (Minister of Public Safety and Emergency Preparedness), [2011] FCJ No 1635. 
The Haj Khalil decision provided the most detailed examination of the duty of care, but it ultimately denied the claim. The court recognized that part of the delay on the application was inordinate and unreasonable. ${ }^{101}$ Madam Justice Carolyn Layden-Stevenson wrote: "It cannot be right that a Convention refugee's application for permanent residence, submitted more than eight years prior, and returned by the Court for redetermination, would not only be put on the back burner, but would be virtually ignored." ${ }^{, 102}$ However, the court noted that delay per se did not mean that the Crown was negligent and did not constitute a free-standing cause of action. ${ }^{103}$ Relying on prior case law, the Federal Court concluded that it would not be "just, fair and reasonable" to impose a duty of care in the absence of "bad faith, misfeasance or abuse of process." ${ }^{, 104}$ The court gave primary weight to the prospect of conflicting public and private duties. It concluded that the recognition of the duty of care could undermine the duty and zeal of immigration officials to investigate thoroughly and, as a consequence, compromise the protection of the public. Ironically, in the case at hand, the delay was not due to an ongoing zealous investigation but, rather, because cases were merely "parked" due to a backlog.

Samimifar and Nkunzimana seem to break away from prior case law as they recognize the possibility of private duties to non-citizens. In Samimifar (decision on a motion to dismiss), the plaintiff faced a nine-year delay on his permanent resident application. ${ }^{105}$ The plaintiff produced evidence that a CIC officer was assigned to his file without requisite clearance and that she continued to ignore the applicant's file, despite requests from others in her department. The case focused on alleged failure to carry out statutory duties and was distinguished from prior case law. Unlike in Benaissa, where the plaintiff made mere assertions that unidentified officers had failed to process his application, $\mathrm{Mr}$ Samimifar was dealing with a specific officer for a prolonged period and was in regular contact with her. Unlike in Home Office, the defendant failed to carry out her statutory duty for a period of seven to nine years. Unlike in Farzam, where the court concluded that it was not reasonably foreseeable that the plaintiff's wife would divorce him because of the processing delay, in Samimifar, the court found it reasonably foreseeable that negligently processing the plaintiff's application would cause him emotional

101 Haj Khalil applied for permanent residence in 1995. There were two periods of delay: 1995-2000 (the first refusal of her case, which was overturned on judicial review) and 2001-onwards (after her case was sent for redetermination). The court assessed the delay during 1995-2000 as "protracted" but did not find it inexcusable or unreasonable, given the CIC resource constraints and the shift in the department's focus of operations from counter-intelligence to countersurveillance to counter-terrorism during that period. However, the delay since 2001 (due to CIC's decision to "park" ministerial relief cases) was determined unreasonable.

102 Haj Khalil, supra note 8 at para 121.

103 As a side note, Haj Khalil's case is far from over, and she still remains in limbo. Following the conclusion of tort litigation, CIC has made a decision on her application. She was found inadmissible, and her application for ministerial relief was denied. She applied for judicial review, and the Federal Court allowed her application against the ministerial relief decision. Haj Khalil v Canada, [2010] FCJ No 1635. Thus, her case was once again sent for yet another redetermination, eighteen years after the grant of the refugee status. Subsequently, she was determined inadmissible the ministerial relief was denied. On review, the Federal Court upheld the inadmissibility decision, but allow application with respect to the decision on ministerial relief. Khalil v Canada (Minister of Public Safety and Emergency Preparedness), [2011] FCJ No 1635. This decision, however, was overturned on appeal and ministerial decision was restored. Khalil v Canada (Minister of Public Safety and Emergency Preparedness), [2014] FCJ No 964. The current situation of Ms Khalil is unknown.

104 Haj Khalil, supra note 8 at para 207.

105 The application was refused due to inadmissibility; the applicant applied for judicial review, which was successful, but no re-determination has taken place by the time of the decision on the summary judgment on his tort action. 
distress and anxiety. ${ }^{106}$ The court concluded that policy considerations did not preclude the imposition of a duty of care where "an immigration officer completely ignores a file." proceed, it noted: "If these facts are true, the actions of Ms. K. and, more generally, CIC officials are far outside of what we expect from our public service. Indeed, failing to impose a duty of care at this minimal level would not be consistent with the principles of accountability of our public service. Surely, there must be some level of service that one can expect in the context of these immigration matters." 108

Nkunzimana did not discuss the duty of care but recognized the civil liability of the Crown under Quebec law. In this case, a Canadian sought to sponsor his orphaned nieces and nephew. Unlike in the earlier cases, the challenge did not concern delays but, rather, the officer's decision making on the application. Mr Nkunzimana filed a sponsorship application in 2001, and it was refused twice: in 2001 and in 2006. The first refusal was due to insufficient evidence of blood relationship between the sponsor and the sponsored, but the decision was overturned on appeal and sent for redetermination. In 2006, the application was refused again but for a different reason - the sponsor's reliance on social assistance at several points in 2004 and 2005. Further, CIC did not find sufficient humanitarian and compassionate $[\mathrm{H \& C}]$ considerations for an exemption. A CIC officer concluded that the five children who lived in a UN refugee camp and were given food, shelter, and medical care, were not in a worse situation than other refugees in the world. This conclusion did not correspond to the evidence: the children were orphans and refugees; they had fled Burundi for Rwanda where they lived in fear and poverty; they shared one small bedroom and had food only for one meal a day; they were waiting for more than five years to reunite with family. The court concluded that CIC's refusal to grant an H\&C exemption deviated from the standard of competency and diligence that could be expected in the circumstances. The applicant's action was allowed and compensation ordered.

Although, at first sight, Samimifar and Nkunzimana seem to stand apart from the other cases, on a closer examination, they confirm the same approach - namely a private remedy may be available only in the most egregious cases. In fact, Nkunzimana noted that the circumstances of the case were "exceptional" so as to warrant a court's interference. Similarly, in Samimifar, the court indicated that the "unusual nature of the claim" had a bearing on the court's decision. Thus, the threshold for recognizing a possible duty of care remains as high as set out in prior case law.

The last case in the group - Premakumaran - alleged negligent misrepresentation of immigration opportunities in Canada. The applicants immigrated to Canada under the economic class, but after eight years and some 4,000 job applications were not able to secure employment in their occupation (accounting). ${ }^{109}$ They had to do menial jobs to support themselves and their children, causing them severe economic, physical, and psychological damage. The applicants argued that CIC's promotional materials and selection criteria misled them (for example, statements such as these: "If your present job description fits our Occupations List, then Canada needs your expertise" ${ }^{110}$ ). The Federal Court granted a summary motion to dismiss. It found no special relationship between the applicants and the immigration authorities; merely picking up an information brochure at a Canadian mission abroad does

\footnotetext{
106 Samimifar, supra note 9 at para 62.

107 Ibid.

108 Ibid at para 67.

109 Premakumaran (CA), supra note 11 at paras 3-5.

110 Premakumaran (FC), supra note 11 at para 15.
} 
not make one a "neighbour." ${ }^{\text {"111 }}$ Further, no specific representations were made to the applicants; the information was general and did not contain any guarantees of work. ${ }^{12}$ The decision did not provide expansive analysis of the duty of care in the immigration context or add further nuance to prior case law, which is likely due to the rather weak facts of the case.

\section{TOWARDS A MORE NUANCED APPROACH TO THE ANALYSIS OF DUTY OF CARE IN THE IMMIGRATION CONTEXT}

As mentioned above, the success of duty of care arguments depends largely on the court's interpretation of factors such as the governing statute, public and private interests, and the policy considerations. In the examined case law, this interpretation was strongly influenced by immigration law's logic, which supports the notion of the state's absolute power to control admission. This notion both justifies the limited nature of obligations towards non-citizens and requires immigration officials to be provided with broad and flexible powers to perform the ultimate task - helping to protect the host society. While increasing the imbalance of power between the host state and non-citizens, this approach, at the same time, militates against granting far-reaching remedies to the latter that may at least partially mitigate this imbalance. In the context of tort litigation, the immigration law logic produces a shallow discussion under the Anns/Cooper test, constructing the duties of officers to the Canadian public as being irreconcilable with proposed private duties and downplaying the importance of timely decision making for applicants. While the existing case law is discouraging, most of it was decided prior to Hill, Odhavji, and Finney, which otherwise may have helped stimulate a more nuanced inquiry into the application of the Anns/Cooper test. In particular, the following aspects of the Anns/Cooper test need deeper and more extensive judicial discussion: the "bad faith, gross negligence or abuse of process" threshold; the articulation of public and private interests; the articulation of policy considerations; and the nature of the governing statute.

\section{A. Threshold}

The first case in the discussed group (Benaissa) noted that it would not be just, fair, and reasonable to impose the duty of care unless there was "bad faith, gross negligence, or undue delay." In subsequent decisions, this phrase reincarnated into "bad faith, misfeasance, or abuse of process" - an arguably higher threshold. While accepting the above threshold, courts did not discuss what amounts to bad faith, gross negligence, or abuse of process in the immigration context. Only two cases provide limited examples of the circumstances that may lead to liability. Nkunzimama suggests that it may happen when a CIC official makes a decision so detached from the real circumstances of the case that it falls below the standard of "a reasonably cautious and diligent person." In Samimifar, this point was reached when an officer was "completely ignoring" the file for at least seven years. At the same time, in Haj Khalil, the court found undue delay and the fact that the application was "virtually ignored" for nearly six years, but it rejected the existence of the duty of care. It is not clear why "parking" cases does not meet the threshold or for how long a file must be ignored to trigger liability.

\footnotetext{
111 Ibid at para 25.

112 Premakumaran (CA), supra note 11 at para 24.
} 
In finding a principled approach to the issue, it is important to keep in mind the rationale behind the remedies addressing bad faith and misfeasance, namely, to ensure that state power is exercised in the public good and not for an ulterior or improper motive. ${ }^{113}$ At trial in Haj Khalil, the former director of security review provided valuable insight into CIC's philosophy: Canada does not "want to keep people in limbo any longer than necessary." 114 A 1998 CIC estimate suggested that there were some 13,000 individuals in a position similar to Haj Khalil's ${ }^{115}$ (unfortunately, more recent data is unavailable ${ }^{116}$ ). What purpose is served by keeping these individuals in limbo? Even if keeping some appliccants in limbo is justified as a means to protect the public, is this objective effectively achieved? For instance, if Ms Haj Khalil were a real threat, then keeping her in limbo (while she was still physically present in Canada and hypothetically could carry out dangerous activities) does nothing to reduce that threat.

\section{B. Articulation of Public and Private Interests}

In the case law that has been discussed, the potential conflict between immigration officials' duty to the Canadian public and private duties to applicants has often led to the denial of proximity. While conflicting duties are a valid basis to negate proximity, it seems that the case law did not analyze in sufficient depth the nature of the duties in question. In the discussed cases, public duties to the host community are clearly articulated and are well understood by the decision makers. They are informed by immigration law rationales and are considered compelling (for example, the protection of the host society). In contrast, the concerns of the plaintiff non-citizens are often not only given low visibility, but they are also not considered to involve fundamental interests. For example, in Paszkowski, the court seemed oblivious to the difficulties posed by the absence of permanent resident status. It was said that as a convention refugee the applicant could continue her education, seek employment, and expand her family; the only major limitation was the inability to travel abroad with Canadian travel documents. ${ }^{117}$ Therefore, the delay in processing was seen merely as an inconvenience. Similarly, both trial and appeal

113 The meaning of bad faith and misfeasance can be usefully illuminated by the recent decision in Finney, which opined that bad faith includes not only intentional wrongdoing, but also serious carelessness or recklessness. Finney, supra note 16 at para 39.

114 Haj Khalil, supra note 8 at para 95. He made this statement in reference to the handling of inadmissible and ministerial exemption cases, explaining that the passage of time could assist positive exercise of ministerial discretion as it can enable the department to gain more information and the applicant to better establish herself in Canada.

115 CCR, supra note 20.

116 There are, however, other examples. For example, Suleyman Goven, a Kurdish refugee, who has been in limbo over permanent residence for thirteen years due to allegations of terrorist activity in his country of origin. He was cleared of these allegations in 2000 by the Security Intelligence Review Committee, but his status was eventually granted only in 2006. In 2005, he filed a lawsuit against the Canadian government for damages. Some twenty more Kurdish refugees are said to be in a similar situation. Statement of Suleyman Goven (11 May 2000), online:

$<$ http://www.cpj.ca/files/docs/statemnt.pdf>. In John Doe v Canada (Minister of Public Safety and Emergency Preparedness), [2006] FCJ No 674, the Federal Court dealt with another case of delay in processing a permanent resident application by a refugee. The applicant was granted refugee status in 1986, but in 2006 there was still no decision on his permanent residence due to security concerns. The court ordered CIC to make a decision within ninety days.

117 Paszkowski, supra note 8 at para 95. 
decisions in Haj Khalil did not fully appreciate the limitations stemming from the absence of permanent residence. ${ }^{118}$

Further, even where the interests of the plaintiff are noted, they are interpreted narrowly. First, references to mandamus as an alternative and more suitable remedy suggest that the courts considered the need for a decision on a pending application as the plaintiff's primary need. However, when a refugee has been waiting for a decision on permanent residence for over a decade, he or she would not only want that decision made but would also want to see someone accountable for such inordinate delays. Nevertheless, this interest is not acknowledged by the courts (except in Samimifar where a reference to accountability was made). When the underlying rationale behind a tort action is not clearly seen by the decision maker, it makes it easier for him or her to collapse the case into an immigration matter with the primary focus on the host state. Thus, the analysis of the duty of care in the immigration context should start with identifying key functions that tort law is to perform in such cases. Arguably, the proper role for tort law in these cases would be to promote accountability, deterrence, and compensation.

\section{Policy Considerations}

Among the key policy considerations militating against the duty of care, the courts named indeterminate liability, interference with performance of immigration control, and the availability of alternative remedies by means of mandamus. The above assumptions are taken as articles of faith without empirical support or much explanation. For example, why are we to automatically assume that the imposition of the duty of care would have a chilling effect on immigration control? Or why would it lead to indeterminate liability? ${ }^{119}$ Due to the current dominance of immigration law logic, the duty of care in relation to non-citizens is constructed as an "us-them" relationship. Recognizing a duty of care is viewed almost as the antithesis to society's interests, a constraint on the sovereign power to control admission and on state's ability to protect the host community. ${ }^{120}$ However, would tort liability not also promote the public good by stimulating improvements in immigration administration and empowering a vulnerable group? Presumably, immigration officers carry out their duties diligently, and there will be relatively few cases where negligence could be established. The decision in Hill is informative as the majority of the Supreme Court of Canada rejected a floodgates argument as speculative in the context of criminal investigations. The Court noted that the police "might become more careful in conducting

118 E.g., on appeal, the court distinguished Hill, supra note 16, on the basis that the harm was not of the "same range of severity" as in Haj Khalil, supra note 8. For discussion of limitations stemming from the absence of permanent resident status, see Andrew Brower, "Permanent Protection: Why Canada Should Grant Permanent Residence Automatically to Recognized Refugees" (2005) 22:2 Refuge 88 at 92.

119 As Klar pointed out, "[1]iability in negligence is never indeterminate." The requirements of proximity and foreseeability along with the notion that a duty can be found only where it is "just and reasonable" impose sufficient constraints. Liability may end up being extensive, but it is not the same as indeterminate. Klar, supra note 77 at para 49 . Kneebone, supra note 5 at $45,389-391$, generally notes that the argument of costs and floodgates are often unsupported by statistics, yet tend to be accepted by courts. She notes that it may be said that the costs and nature of litigation will be a sufficient deterrent against unmeritorious claims.

120 The duty of care is generally seen as a restriction on individual freedom for the sake of collective well-being. Desmond Manderson, Proximity, Levinas, and the Soul of Law (Montreal and Kingston: McGill-Queen's University Press, 2006). 
investigations" but that "is not necessarily a bad thing." " Similarly, the interests of the host community and non-citizens do not have to be viewed as irreconcilable (our security versus their need for protection) but, rather, can be interpreted as both fitting common societal objectives.

\section{Governing Statute}

The nature of the governing statute perhaps is the most formidable obstacle to the recognition of the duty of care in immigration. Viewed as the ultimate expression of immigration law's essence and of the "us-them" divide, the IRPA cannot allow the host state and the non-citizen to be proximate. However, this characterization appears accurate only at first sight. The Act deals with various classes of migrants economic immigrants, family reunification, temporary migrants, and refugees - each producing a distinct state-non-citizen relation. For example, while obligations towards economic immigrants are minimal and are highly unlikely to support the duty of care arguments, those towards refugees fall at a higher end of the spectrum and may create proximity sufficient for a prima facie duty of care. In relation to family immigration, there may be different degrees of proximity between the sponsor and the state versus between the state and the sponsored family member. ${ }^{122}$ To date, courts have focused mostly on the objectives of the IRPA to determine the nature of duties under the Act. A deeper analysis based on respective parts of the $I R P A$ that deal with a particular immigration class in question could help develop a more nuanced understanding of the nature of the relationship between the state and a given applicant. Such an approach may also help alleviate policy concerns about unlimited liability. For example, even if the duty of care is recognized in relation to refugees, it does not mean that it would automatically extend to other classes of immigrants.

\section{CONCLUSION}

In the jurisprudence on immigration-related torts, we observe the collision of a relatively certain identity of immigration law, which focuses on the interests of the host community, with a more uncertain identity of tort law, which is represented by multiple visions of its rationales and functions, dancing on the line between public and private. ${ }^{123}$ These two colliding logics create a complex backdrop for the analysis of the duty of care. The matter is further complicated by the fact that immigrationrelated torts involve potential liability of public officials (an area where the courts may be more reluctant to extend liability) and are strongly influenced by the IRPA framework, which reinforces the separation between the state and the non-citizen. So far, the courts have not fully met the challenge of negotiating

Hill, supra note 16 at para 56.

122 E.g., in Whiteman, supra note 13 at para 96-97, the Ontario Superior Court noted: "It is not every decision and every process carried out by immigration officials that will give rise to a private law duty of care. There are a diverse array of decisions and processes within immigration law and they can arise in widely different circumstances ... The flaw in the approach taken to the present Motion by Canada is that it effectively seeks to immunize all decisions and processes of immigration officials, in all circumstances, instead of analyzing the particular circumstances of this case in the context of its particular statutory scheme and then applying the Anns/Cooper factors to that specific context."

123 If in the nineteenth century, tort law was viewed as a strictly private matter between the plaintiff and defendant, the twentieth century brought increasing realization that tort law is connected to policy and society-wide considerations, leading some to characterize tort law as "public law in disguise." Tort law lies at the intersection of private and public just as injury has a public and a private dimension. White, supra note 45 at 219, 338 . 
and dissecting these complex narratives. In most cases, the discussion does not advance past the traditional point that the state has the absolute power to control admission and that such power is necessary to protect the host society. What is lacking is a consideration of the underlying issues affecting the proper exercise of state powers and accountability (as they relate to the current threshold of bad faith, misfeasance, or the abuse of office) as well as an appreciation of the multi-faceted nature of public and private interests in immigration and of the distinct dynamics between the host state and each class of migrants (economic, family, or refugee). While these considerations do not guarantee a finding of a duty of care, fairness requires that at the very least all relevant issues are explored in their full complexity. 